\title{
Fading of Dolanan Functions (Tradisonal Game) Java in the Millennial Generation in Binjai City
}

\author{
Nila Afningsih* and Debbi Chintya Ovami \\ Universitas Muslim Nusantara Al Washliyah Medan, Indonesia \\ *Corresponding author email: nilaafningsih@umnaw.ac.id
}

\begin{abstract}
The purpose of this research is to see how the process of Dolanan (traditional game) fading occurs in the Millennial Generation in Binjai City. This type of research is descriptive qualitative. Population in community research in the city of Binjai. The research method used was the triangulation technique. The results showed that Dolanan (traditional game) in North Sumatra was not transmitted well. There are clear boundaries between the first and fourth generations. The first generation still mastered traditional Javanese games, while the fourth generation did not know the game at all. This finding strengthens the statement that the Dolanan (traditional game) in the city of Binjai is threatened with extinction and needs to be revitalized before this traditional game is totally extinct.
\end{abstract}

Keywords: Javanese Dolanan (Traditional Game)

\section{INTRODUCTION}

The young generation, especially in Binjai City, is currently in a "blind" position to cultural values. They forget and do not preserve their original cultural values. As a result, they are alienated and eliminated from the original cultures [1]-[5].

Dolanan (traditional game) is a game and/or sport activity that develops from a custom of the Javanese tribe in Indonesia. Dolanan (traditional game) is often used as a type of game that has native regional characteristics and is adapted to local cultural traditions. Its activities are intended to seek entertainment and fill spare time after being separated from routine activities such as work and school [6]-[9].

In its implementation, Dolanan can include elements of folk games and children's games into it. It is even possible to include activities that contain artistic elements such as those commonly referred to as traditional arts. Child games are a nation's cultural wealth that has noble values that can be passed on to children as the next generation. Traditional children's games provide benefits for child development and are the nation's cultural assets [10]-[18]. In general, Dolanan will teach children to be able to socialize and hang out with their peers because children's games are generally carried out in a large open space, and involve many people to play them. Dolanan can also be used as therapy for children. When playing, children will release their emotions. They screamed, laughed and moved.

The city of Binjai is a city where traditional games are extinct in Binjai City. This happened not only because it was carried away by the changing times but the biggest factor was the family and environmental factors which were lacking and even no longer introduced Dolanan (traditional games) to them. one more thing is that the millennial generation is more interested in games developed by technology. By looking at the background of the condition of the millennial generation of Binjai City, the research tries to find and see the process of extinction of the Dolanan (traditional game) in the city of Binjai. Specifically, this research is aimed at finding and observing the process of the extinction of Dolanan (traditional games) in the city of Binjai.

\section{METHODOLOGY}

This research is more descriptive in nature with a qualitative ethnographic approach. This study seeks to show and shape the structure of the socio-cultural life of a 
society and to compare social systems in order to obtain general rules that are common in society [19].

The techniques used to collect data in this study were interviews, observation and documentation.

\subsection{Interview}

The interview technique used by researchers in this study was semi-structured interviews. According to Sugiyono [19], the purpose of semi-structured interviews is to find problems more openly, in which the parties who are interviewed are asked for their opinions, and their ideas. Furthermore, interview addressed to community leaders and residents around the city of Binjai and also to the younger generation in the city of Binjai. Interviews were conducted using interview guidelines that have been made by the researcher. The questions that have been made by the researcher in the interview guide can be developed according to the information needed during the interview so that the interview can run openly but still focus on research problems. From these interviews, the researchers managed to obtain the data and information needed in research on Dolanan (Javanese games) in Binjai City.

\subsection{Observation}

This research used direct observation and uses a type of passive participation observation. According to Sugiyono [19], passive participation means in this case the researcher comes to the place of the activity of the person being observed, but is not involved in the activity. With direct observation, the researcher made observations to find data which later became one of the data sources which could then be processed into material for analysis. In this study, the researcher observed the development and use of Javanese oral tradition in the city of Binjai, especially the Javanese people.

\subsection{Documentation}

According to Sugiyono [19], documents are records of past events. Documents can be in the form of writings, pictures, or monumental works of a person. Sugiyono [19] explains that the results of research from observations or interviews will be more reliable if they are supported by documents.

\section{RESULTS AND DISCUSSION}

\subsection{Results}

This research in data collection using the triangulation method. The triangulation technique used in data retrieval with interviews using technical triangulation and source triangulation. This process is carried out in order to produce information that has a high level of credibility and can describe the real information that occurs in the interaction space. Technique triangulation consists of observation, interview and documentation. The process carried out by the researchers is to visit the research site, observe the actors in the research, and be in the interaction room to find out how far they are familiar with the Javanese oral tradition, especially for those who are Javanese.

The following is the research data that has been done. The interview technique was carried out by determining representative sources in advance who were in accordance with the research question. In this study, the respondents were community leaders and teenagers in the city of Binjai. From the interview results, Dolanan (traditional game) in Binjai City is almost extinct. This doesn't just happen. From the results of interviews with informants, namely community leaders who are considered to have experienced the shift of Dolanan (traditional game), that its extinction occurred through a process of several generations.

Changes in traditional games often occur in every generation. This is due to various things, one of which is that the development needs of each generation have changed. The following is the process of shifting the existence of Dolanan (traditional games) that has occurred in several generations.

1. First Generation Javanese Dolanan (traditional game). This first generation is a generation with an age range between eighty years and a hundred years or even more, namely the oldest or oldest generation group. This group only has very limited activities, namely in the home or family environment. They only interact with their children, son-in-law, grandchildren, living relatives, and their closest neighbors. They no longer participate in social activities in a wider environment due to limited physical abilities. The first generation still staunchly mastered the traditional game.

2. Second Generation Javanese Dolanan (Traditional Games). The second generation, ranging in age from fifty-one to seventy-five years, is the older generation group. When compared to the elderly, this group has a wider range of activities, namely in the home environment, the neighborhood, and the work environment that is more heterogeneous. They have higher mobility than the elderly group. They interact with their children, son-in-law, grandchildren, relatives, neighbors, and friends outside their environment. They still participate in community social activities in a wider environment because from a physical capacity perspective it is still possible. The second generation still uses traditional Javanese games. This traditional Javanese game is still played in their daily life. They form a friendship with their friends in their time with traditional games, this is because these games are generally played together or in groups. In this generation there are still many traditional games that are always played by them, for example cublekcublek suweng, gobak sodor, marbles, cranks, gatheng, engrang, ularnaga, patil lele, etc.

3. Third Generation Javanese Speakers. The third generation, with an age range between twenty-six and fifty years, is a group of the younger generation. When 
compared to the elderly and elderly groups, this group has a wider range of activities, namely in the home environment, the neighborhood, the work environment, and other social environments that are more heterogeneous. They have relatively high mobility compared to the elderly and elderly groups. In the third generation, there are still Javanese traditional games that were passed on by past people. In this generation, the traditional game has begun to experience a crackdown on naming. For example, the game Cublakcublak Suweng has changed the song to Pak-Pak Uden wanting to marry. Gantheng became confused. And in this generation, there are still many who know and play traditional games.

4. Fourth Generation of Games (Traditional Games). The fourth generation can be said to be the generation who is less familiar with traditional games, although there are some games that have survived until now, such as marbles and kites. Some of the causes of the fading of Javanese dolanan (traditional games) are that their rua people do not teach traditional games to their offspring. And the most obvious cause is games developed by technology, for example, online games that they can play using mobile phones. The rapid development of technology has apparently been able to shift the existence of traditional Javanese games in the city of Binjai.

\subsection{Discussion}

The data above shows that Dolanan (traditional games) in the city of Binjai is not well transmitted. There are clear boundaries between the first and fourth generations. The first generation still controls and uses Javanese Dolanan for playing and gathering, while the fourth generation is no longer familiar with traditional Javanese games such as cublak-cublak suweng, engrang, Patil lele, and others. Millennials in the city of Binjai are more familiar with instant games that they can watch or play via cellphones, gedget or on the Internet today. This finding strengthens the statement that Dolanan (traditional game) is threatened with extinction and needs to be revitalized before these traditional games become extinct. As the opinion of Crystal [20], which states that language experiences death when no one speaks the language anymore.

After making observations, the researchers and other informants found several things that affect the extinction of Dolanan (traditional game) in the current era. This is influenced by several factors as follows.

a. The occurrence of inter-tribal marriages

b. Parents (Generation III/Javanese Pujakesuma) do not introduce Javanese game (Dolanan) and Javanese culture to their children.

c. Living in an environment that has a mix of tribes.

d. Modern games developed by technology are more in demand by the millennial generation in the city of Binjai.
The intergenerational transition that is taking place among users of Javanese traditional game (Dolanan) in Binjai City can be overcome through an awareness movement to maintain culture as part of Javanese ethnic identity. Local governments should not appear to turn a blind eye to this identity crisis. The death of various cultures and the traditional games of Javanese culture also means the death of national culture.

\section{CONCLUSION}

Based on the results of the research and discussion in the previous chapter, it can be concluded as follows.

1. From the results of interviews, observations, documentation that Dolanan (traditional game) in the city of Binjai has already experienced extinction, especially the millennial generation in that city, most of whom do not know Javanes Dolanan (traditional game), especially for Javanese ethnic groups.

2. The extinction of traditional Javanese games in Binjai City occurred not only because they were carried away by ancient times, but the biggest factors were family and environmental factors that did not introduce them to Dolanan (traditional game). In addition, our youth are more interested in technological developments.

\section{REFERENCES}

[1] Y. M. Supriatin, Oral literature and National Identyty: The Case Study of Indigenous Village Sinar Resmi, Sukabumi. Patanjala, 4 (3) (2012), 407-418.

[2] H. Hamzah, M. S. Ab. Karim, M. Othman, A. Hamzah, N. H. Muhammad, Challenges in Sustaining the Malay Traditional Kuih among Youth. International Journal of Social Science and Humanity, 5 (5) (2015), 472-478.

[3] R. Muhammad, M. S. M. Zahari, K. M. Abdullah, M. S. M. Sharif, Young Generation Practices on Malaysian Ethnic Festival Foodways. Procedia - Social and Behavioral Sciences, 170 (2015), 300-307.

[4] P. M. Geldens, S. Lincoln, P. Hodkinson, Youth: Identities, transitions, cultures. Journal of Sociology, 47 (4) (2011), 347-353.

[5] Z. Qin, Y. Song, Y. Tian, The Impact of Product Design with Traditional Cultural Properties (TCPs) on Consumer Behavior Through Cultural Perceptions: Evidence from the Young Chinese Generation. Sustainability, 11 (426) (2019), 17 pages.

[6] Daryanto, F. Nuryantiningsih, W. D. Pandanwangi, Nilai Edukasi Dan Kearifan Lokal Dolanan Anak 
JawaSebagai pembentuk Karakter Anak. Prosiding Seminar Nasional dan Call for Paper, Jurnal LPPM Universitas Jendral Soedirman Purwokerto, (2017), 1256-1265.

[7] A. M. M. Sari, S. Hartati, T. Sumadi, Tembang Dolanan Jawa sebagai Media Pendidikan Karakter. Indonesian Journal of Educational Counseling, 4 (2) (2020), 125-132.

[8] W. S. Suherman, S. Nopembri, N. R. Muktiani, PENGEMBANGAN "MAJEDA" BERBASIS DOLANAN ANAK UNTUK MENGOPTIMALKAN TUMBUH KEMBANG SISWA TAMAN KANAKKANAK. Cakrawala Pendidikan, 36 (2) (2017), 220232.

[9] A. Suprayogi, Fenomena Lagu Dolanan "GundulGundul Pacul" dalam Pendidikan Karakter Anak dan Ranah Sosial. Imaji, 6 (2) (2018), 109-117.

[10] Sedyawati, Permainan Anak-Anak sebagai Aspek Budaya, Refleksi Budaya dan Wanaha Tumbuh Kembang Anak. LPM Sosiatri Fisipol UGM, (1999).

[11] P. N. Widiasavitri, N. M. Y. A. Agustini, D. P. Astiti, L. M. K. S. Suarya, T. Haryati, Traditional Games as Alternative Activities for Children Stimulation. Journal of Psychology and Instruction, 4 (1) (2020), 1-9.

[12] Ambretti A., Palumbo C., E. Kourkoutas, Traditional Games Body and Movement. Journal of Sports Science, 7 (2019), 33-37.

[13] R. E. Sulistyaningtyas, P. Y. Fauziah, The Implementation of Traditional Games for Early Childhood Education. 3rd International Conference on Current Issues in Education (ICCIE 2018), Advances in Social Science, Education and Humanities Research, 326 (2019), 431-435.

[14] Y. A. Nugraha, E. Handoyo, S. Sulistyorini, Traditional Game on The Social Skill of Students in The Social Science Learning of Elementary School. Journal of Primary Education, 7 (2) (2018), 220-227.

[15] W. S. Suherman, Dapan, Guntur, N. R. Muktiani, Development of Traditional Children Play Based Instructional Model to Optimize Development of Kindergarteners' Fundamental Motor Skill. Cakrawala Pendidikan, 38 (2) (2019), 357-365.

[16] Z. Tatli, Traditional and Digital Game Preferences of Children: A CHAID Analysis on Middle School Students. Contemporary Educational Technology, 9 (1) (2018), 90-110.
[17] A. Lestariningrum, The Effect of Traditional Games, Self-Confidence, and Learning Style on Mathematical Logic Intelligence. International Conference of Early Childhood Education (ICECE 2017), Advances in Social Science, Education and Humanities Research, 169 (2018), 8-12.

[18] N. K. A. Rahmadani, L. Latiana, R. A. Aen, The Influence of Traditional Games on The Development of Children's Basic Motor Skills. International Conference of Early Childhood Education (ICECE 2017), Advances in Social Science, Education and Humanities Research, 169 (2018), 160-163.

[19] Sugiono, Metode Penelitian Kuantitatif Kualitatif Dan R\&D. Bandung: ALFABETA, (2010).

[20] D. Crystal, Language death. Cambrige University Press, (2000). 